\title{
Embodied Vibrations
}

Disastrous Mobilities in Relocation from the Christchurch Earthquakes, Aotearoa New Zealand Gail Adams-Hutcheson

\begin{abstract}
This article contributes to debates that consider things (buildings) that have previously been assumed to be bounded and fixed. When thinking about how literally anything can become mobile, this article addresses how buildings "live on" through the bodies of participants. The notion of material affects is advanced to draw together a complex set of ideas on vibrant materialities. Material affects, then, entangle the earth, forces, embodiment, and micromobilities to expose the vibrant matter of buildings. Empirical material is drawn from semistructured interviews with people who relocated out of Christchurch following the 2010 and 2011 earthquakes and aftershocks. In relocation, acute spatial awareness and sensitivity to movement and vibration — that is, the minute shudders and flexes of buildings—colonized the bodies of participants. Material affects are able to challenge the distinction between vital energy (life) forces and materiality.
\end{abstract}

Keywords: Christchurch, earthquakes, geography, geopower, material affects, mobilities, trauma

\section{Earth-Bodies-Moorings}

In 2006, Peter Adey outlined how scholars must realize how things appear and work in incredibly mobile and wavelike ways, while also not reducing mobilities to a featureless, homogenous conglomerate. ${ }^{1}$ Affective materialities instead expose the differences and heterogeneous relational elements between movements, forces, and bodies. By advancing material affects, which cojoin bodies, buildings, vibrations, and the earth, this article argues for 
heterogeneous assemblages that are mobile. Quite simply, life is considered more than a vital energy that must distinguish itself from materiality. Humans and nonhumans (things) can be transformed and set on divergent trajectories by variously temporized forces such as earthquakes. Earthquakes imply entire multitudes of varying mobilities and assemblages at different scales. ${ }^{2}$ Not only the ground moves through seismic motion, but people move through internal and external migration (relocation), and they tell moving stories imbued with emotion. Earthquakes roll and buckle the earth, creating momentary upheavals, in turn causing inanimate objects, such as buildings, to jump, shudder, roll, collapse, lean, sway, bend, and break. People too are propelled into various mobilities. Bodies can be infused with shock and become inanimate, unmoving and still; some bodies crouch low, taking cover. Yet others walk, run, jog, or sprint, hearts thumping, sweat beading on clammy skin. Mobility frameworks are used here for an indepth analysis of what Jane Bennett terms "vibrant matter," 3 that is, the active, earthy, not-quitehuman capaciousness that mingles with the material affects of buildings.

Allowing for deliberation on the fluidity of buildings and consideration of elemental mobilities, ${ }^{4}$ I draw attention to material affects to interrogate how buildings "live on" and vibrate through the participants' bodies. Vibration has been described in various ways; for example, Elizabeth Grosz examines how vibration intensifies passion. She suggests "there is something about vibration and its resonating effects on material bodies that generates pleasure, a kind of immediate bodily satisfaction" as bodies vibrate to the hum of the universe. ${ }^{5}$ But more than pleasure, vibrations, depending on the relational link to them, can evoke horror, anxiety, and fear. Far from inert or passive, vibrations, then, have the "generative capacity to do things." ${ }^{6}$ In this article, vibration (like jet lag) is considered a disruptive experience, one that "agitates, confuses, dis-orders, disturbs, interferes with, interrupts, upsets and unsettles." ${ }^{7}$ The recognition of these 
affective materialities recenters the corporeal body as an affective vehicle through which place and movement are sensed, in order to construct and extend work on how buildings become mobile.

Like Bennett, I use Spinozian thinking on affect in two ways, that is, his explanation of the ability or force within bodies to affect and to be affected, and the ways in which he alludes to vibrant matter. For example, Bennett quotes Spinoza to explore how he ascribes particular vitality to things. Spinoza states that "even a falling stone is endeavoring, as far as in it lies, to continue in its motion." 8 Thus, I draw on both Spinoza and Bennett to describe how bodies and buildings have a particular vitality. Since emotion and affect are inseparable from human experience, and our bodies are always located in a context, I link the two terms. Joanne Sharp discusses a debate that kindled over the distinction between emotion and affect, such that emotion can be considered as individual/personal and affect as transhuman/political. ${ }^{9}$ Throughout this article, however, I choose to consider emotion and affect as intimately connected and use the terms interchangeably. ${ }^{10}$ Emotion and affect afford a focus on the curiously rich and unruly nature of what is usually unspoken in everyday life, as well as rhythms, vibrations, moods, and bodily capacities, and the ways in which these seemingly disparate elements collude into complex assemblages.

This article advances thinking on the co-constitutional relationships between people and buildings that are molded by micromobilities. Material affects, then, entangle the earth, forces, embodiment, and mobilities to expose the vibrant matter of buildings. Attention is paid to material affects but also to the spatial consequences of these affects, which may recalibrate the force, friction, route, speed, and experience of seismic tremors (earthquakes). ${ }^{11}$ In the next section, the context of the Christchurch earthquakes is presented with a brief commentary on 
housing insurance and its effect of halting relocation mobility for homeowners. Following this, the affective materialities of buildings are explained. In the event of an earthquake, buildings are thought of as anything but static, which aligns with how scholars have reimagined buildings as fluid, dynamic, and in flux. I push these ideas to include how buildings have affected participants and live on through "vibration contagion.” The second half of the article takes up an in-depth investigation of vibration, analyzing how somatic jolts cause both an acute spatial awareness of risk, as well as how these jolts come to be shared and reimagined in similar spaces but sometimes in radically different bodies and places.

\section{Relocated Cantabrians in Waikato}

Beginning on 4 September 2010, the people of Christchurch have had to endure more than ten thousand earthquakes and aftershocks. Of this estimated total of earthquakes and aftershocks, four hundred have been greater than magnitude 4.0, and more than forty have been over magnitude 5.0. ${ }^{12}$ Christchurch’s earthquakes have impacted many people’s lives in New Zealand. In particular, having two major events six months apart was especially difficult for residents, and in response, some people decided to relocate.

Local people were significantly impacted by living for months on end with strong aftershocks that took an enormous toll on the residents of Christchurch. It was said that most people could cope with the first two major earthquakes and deal with the losses, but the next two on 13 June 2011 and 23 December 2011 “particularly dented psychological resilience.”13 The major jolt on 23 December was especially cruel, prompting a great deal of angst, doubt, and (re)trauma among the people who stayed. The empirical work for this article is based around PhD research conducted from 2011 to 2014 on people who relocated out of Christchurch, 
Canterbury, to Hamilton, Waikato, on the North Island.

For the project, nineteen semistructured interviews were completed, of which eighteen were with households (encompassing approximately sixty-two people) and one with an individual in a disability day-care facility. Overall, interviews were undertaken in the private homes of respondents, with only one couple deciding to meet somewhere else, and a single person was in a disability day care facility. Participants had been living in the Waikato region for short periods of time (some as little as two months) and considered that they had relocated to Waikato on a permanent basis. Out of the eighteen families included, only six relocated directly after the second massive earthquake on 22 February 2011. Relocation, then, was often considered a "last resort" decision.

Mobility is, of course, a resource that is differentially accessed. One person's speed is another's slowness, and there is clearly a politics of mobility when considering the postdisaster environment. ${ }^{14}$ In the case of Christchurch, many people were hypermobile in the immediate aftermath of the most damaging and deadly earthquake on 22 February 2011 (185 deaths). Mobile phone data traced the out-migration from Christchurch at approximately seventy thousand people; however, this figure changed dramatically over time as people returned to assess damage to homes and begin the long process of repair through insurance claims. ${ }^{15}$ The government insurance program, the Earthquake Commission (EQC), managed residential claims. EQC provides earthquake and fire insurance that is required with every mortgage, and approximately 95 percent of New Zealand homeowners have EQC-backed earthquake insurance coverage. ${ }^{16}$ Therefore, homeowners with mortgages and/or other financial responsibilities tended to be far less mobile than people who rented, the main cohort of this study.

Experiences of the people who left Christchurch cut across a number of the "constituent 
parts" of Tim Cresswell's thinking on the politics of mobility, reframing relocation as an inherently political experience. ${ }^{17}$ Certainly, there is a political agenda integral to thinking about the mobile practices and representations of earthquake survivors. Politics are also highly visible with other disasters, such as the evacuation capabilities (or not) of New Orleans residents in the Ninth Ward and beyond. ${ }^{18}$ The why and who moved in the wake of the earthquakes and aftershocks in Christchurch have been examined, as well as how people spoke about the relocation experiences. ${ }^{19}$ Here, a much closer embodied inspection of the "how does it feel, and when and how does it stop" ${ }^{20}$ in relocated spaces is taken up. This article engages with the "new" mobilities paradigm outlined by Mimi Sheller and John Urry and ten years on by Mei-Po Kwan and Tim Schwanen, and enmeshes materiality with embodiment. ${ }^{21}$ The distillation of complex somatic and kinesthetic geographies allows (im)mobilities to collide and inform one another, pushing the spatiotemporal analysis of vibration.

Henri Lefebvre’s Rhythmanalysis aids reflection on embodied vibrations by investigating how rhythms shape human experience. Each person carries with them a host of embedded and embodied forms of social knowing that regulate social life and space. ${ }^{22}$ It is difficult to think about a city without considering the rhythms that are essentially a dynamic part of the multiplicity of flows that emanate from, pass through, and center on a place, as well as contributing to its situated dynamics. Where there are rhythms, however, there are also counterrhythms and arrhythmia; one implies the other. When the earthquake disasters struck the city of Christchurch, the human practices that are part of the continuous processes "of emplaced engagement with the material, sensory, social and cultural context” abruptly halted in the central city and were diverted to other parts of the surrounding areas. ${ }^{23}$

The earthquakes changed the rhythmic dynamics of the city, with hot spots of resources, 
help, support, and personnel flowing into more stabilized parts of the city (northwest), while simultaneously other parts were cleared and cordoned off (CBD and eastern suburbs). ${ }^{24}$ In the aftermath of the first response waves, the central city was shut down, fenced off, and controlled by the New Zealand Army. Despite the fluidity of rhythm at multiple scales, an event of large magnitude caused major disruption, leaving people out of place, out of time, and out of step with everyday life rhythms. Ash Amin and Nigel Thrift examine the regular comings and goings of people about city spaces, which is extended by considering the fractured time/space and respecializations imposed by disaster. ${ }^{25}$ The implied repetition of rhythm and habit come sharply into focus when they are suddenly halted or missing. The regular repetitive rhythms of life become a "part of the way things are," which can lead to an "ontological predictability and security.”26 Lack of these organizational processes of rhythms and habit can lead to discomfort, distress, and suffering. As such, many people try to restore "familiar spaces, routines and timings to minimize discomfort." ${ }^{27}$ I argue that in relocated places, however, daily life disruptions continued. In the next section, I overview writing about the material affects of buildings and the notion of geopower to consider how life forces, bodies, the earth, and buildings are woven into complex assemblages.

\section{Buildings}

Geographers have "explored the way the built environment is shaped and given meaning through active and embodied practices by which it is produced, appropriated and inhabited." ${ }^{28}$ An individual's attachment to their surroundings is constantly negotiated as the body moves around space, which counters the claim that place and space are static. The ongoing interactions between bodies and things in the world alters the affective capacity of body and landscape, and in 
particular, I hone in on the built urban environment. The idea of the mobility of buildings and within buildings is one strand of Deleuzian thought (the force of things) that has been of value in architecture. Elizabeth Grosz examines the co-constitution of the earth, bodies, space, and architecture through the term "geopower." Her work is a good starting point from which to think about the engagement of affective materialities, which tie the earth, bodies, and buildings together. As Nigel Clark notes, “Grosz’s notion of geopower permits the dynamics of the earth to leave their mark on human and other bodies." ${ }^{29}$ Thus, the "relations between the earth and its various forces, and living beings ... are forms of geopower.”30

The usefulness of material affects as a concept is in the way in which these intensities are not confined to the body of the individual but can become shared and (re)imagined in different spaces and contexts. Nigel Thrift explains that cities may be seen as roiling maelstroms of affect. Particular affects, he argues, "are continually on the boil, rising here, subsiding there,” and these affects incessantly "manifest themselves in events which can take place either at a grand scale or simply as part of continuing everyday life.”31 In order to reflect on buildings and the built environment from an affectual perspective, I consider how cities are often thought to have a vibe or buzz. These affective feelings exist in a fluid context. For example, Christchurch changed from a tourist-orientated “Garden City” that resonated with the energy of a colonial settler past written into and onto historic buildings, to evoking a feeling of destruction, gaps, dead space, and silence, and then a "rising from the ashes" noisy amalgam of construction vehicles, workers, and technologies.

Paying attention to disaster underscores the hypermobility of daily contemporary life, particularly when these complex systems break down. ${ }^{32}$ There is an impetus, then, to examine what happens when fixities, such as buildings, are propelled into motion. Interrogation and 
expansion of thinking on moorings—in this case, buildings—is important. Buildings have been conceptualized as static, immobile, unmoving, implacable, and solid in the face of history; however, this has been challenged by scholars examining materiality and force. ${ }^{33}$ Jane Jacobs and Stephen Cairns have considered how architecture is animated, by holding together or not holding together, that is, how buildings are in a state of constant change, the authors instating a denial of death. ${ }^{34}$ As Adey explains, "buildings, possibly the hardest and envisioned as the most immobile of things, are being imagined in terms of the rational extensity and fluidity they embody.”35 Part of the true horror of earthquakes is their ability to move the seemingly unmovable; it is often said that "earthquakes do not kill people, buildings do." ${ }^{36}$ In Christchurch, the Canterbury Television (CTV) building was responsible for 115 of the 185 deaths, while falling masonry and other buildings accounted for most of the others, with eight people losing their lives on buses and twelve in the suburbs. ${ }^{37}$

Buildings played a dramatic role, engendering varied affectual responses in participants. Shockwaves thrust through, under, and along the earth’s crust, moving, shaking, and rolling roads, power lines, sewer pipes, cables, foundations, bricks, and mortar. Adding earthquakes into the mix means that technologies and fixities or moorings are sometimes (quite literally) turned upside down. Buildings moved, they fell, and parts of them scattered across streets, their mortar dust rising into the air. By incorporating the dynamic impact of the earthquakes on structures, causing vibrations to ripple outward, the focus is on how concrete shudders and flexes minutely in the everyday. Sensitivity to the flex and sway of large buildings, which often goes unnoted, invaded the spaces of relocated survivors, curbing their interactions with the built environment. To respondents, buildings were conceptualized in complex and ambiguous terms: they contained precious memories; were able to instill fear and relief, despair and safety (home), and mobilized 
community responses; and created moments of calm, grief, and feelings of entrapment. In the next section, I explain the continuing relationships to buildings in the relocated city of Hamilton, a stable and earthquake-free zone.

\section{Acute Spatial Awareness}

Interviewees often talked about an embodied sense of acute spatial awareness, particularly around commercial buildings. Shopping malls, integrated glass-and-concrete structures, and high-rise constructions tended to inhibit their interactions with the built environment in Hamilton. For respondents, the relocated urban landscapes were seemingly punctuated with "no-go zones," disrupting the typical consumption rhythms that make up the interactive flows of cities. Large shopping malls, in particular, held significant fear for earthquake survivors, but multistory buildings and cinemas did as well. Many related that large glass-and-concrete structures were the most formidable, because the buildings could account for high numbers of deaths during an earthquake (such as in the CTV building in Christchurch). Angela recounts a large shopping mall in east Christchurch: "I saw large parts of the EastGate Mall come down, the damn thing fell apart right in front of my eyes! Can I bring myself to go into the Base or Chartwell [shopping malls in Hamilton]? No way! I struggle mightily with letting my children go there; you won’t get me back in one of those things, ever.”38

Cinemas too held notions of terror that brought forth intense bodily reactions such as panic attacks, profuse sweats, and feeling physically ill and/or needing to race to the bathroom. When asked, Jackie comments, “Do I get physical reactions still? Um, yes, abject fear in cinemas and malls. Just sitting in the dark I feel physically ill, and anxious, and I immediately need to pee, so maybe that means I'm not anywhere near over the earthquakes." ${ }^{39}$ Jackie's feelings about the 
cinema and shopping malls and the effect of the earthquakes and aftershocks on her outlook and future feelings of safety were a common thread within interviews. Participants often saw cracks in houses, roads, and pathways as visible signs of movement, igniting relational flows of feeling that linked directly back to the earthquakes and Christchurch. "We all do it constantly! We walk around and say, well, that building wouldn't last in a 4 [magnitude earthquake]." ${ }^{, 0}$ Respondents had hyperawareness of their bodies in space(s)—constantly reframing the skyline with risk assessment analysis, noting which buildings were likely to "survive" or come down with varying magnitudes of earthquake and aftershock stresses. This led to thinking about how participant bodies were colonized by the earthquakes. Respondents not only thought about the relocated landscape differently; they also felt it differently from people who had not experienced the earthquakes and aftershocks.

\section{Somatic Jolts}

The corporeal experience of (im)mobilities is an important focus of this article; in particular, David Bissell's work on vibrating materialities has salience. ${ }^{41}$ Paying close attention to the micromovements of commuters and, indeed, the movements of the trains themselves, Bissell exposes how "vibrations unsettle our taken for granted ways of separating out different materialities as they cut through different human/nonhuman materialities, whilst simultaneously bringing them into being in new ways." He examines the "small, not exactly traumatic, but certainly unrelenting shakes, quivers and vibrations that the body-in-transit has to endure to move," which differs somewhat from violent earthquake shudders of varying length, velocity, and frequency. ${ }^{42}$ However, in both cases there is emphasis placed on the memory of those vibrations that seem "most inescapable." ${ }^{43}$ In the traveling body, motion is folded into bodies, 
whether from trains, airplanes, ships/boats, or cars, and often takes time to leave, mostly experienced as forms of motion sickness. Earthquake survivors too continued to feel the motion of aftershocks long after the shaking ended.

Sketching the somatic qualities of the disaster reveals how the earthquakes' initial ruptures and shockwaves not only work through bodies but also inhabit them over time and reignite in different spaces. The temporality of earthquakes is then extended, as the vibrations are carried in the body and are able to be rekindled when similar configurations line up, not unlike trauma. The experience of trauma, fixed or frozen in time, refuses to be represented as past but is perpetually reexperienced as a painful, disassociated, traumatic present. ${ }^{44}$ And likewise, Sam considers that vibrations from heavy vehicles "actually feel like an earthquake, and suddenly I am back in Christchurch, the images flash past my eyes and my heart lurches at a hundred miles an hour." 45

Within the research interviews, many of the respondents outlined their acute bodily reactions to the vibrations felt through the ground, or within buildings, when articulated lorries (semitrailer trucks) passed by. Angela notes that "the trucks make noises just like before an earthquake—you can feel the vibrations through the floor [of my shop], rumble, rumble, rumble — that's exactly what the first five seconds of an earthquake feels like. My son dove under the counter the first time a truck came past." ${ }^{, 6}$ The bodily reaction to these felt vibrations are often momentarily overwhelming. Josh continues, “I know it’s not an earthquake, but my reaction is the same: I get an adrenaline shock, my heart slams into my chest, and I'm ready to dive under cover. ${ }^{\$ 4}$

Lucy Budd, David Bissell, and Jon Anderson ${ }^{48}$ have considered differing forms of bodily mobility and have galvanized an interest in the consequences of mobility of those involved in 
various forms of travel. What has been less explored is the idea of motion sickness, particularly disembarkation sickness, which settles into the body for some time after the particular mode of

traveling. ${ }^{49}$ In this sense, relocation is forced travel or movement away from the postdisaster city. But it is also extended to consider what remains in the body once the mobile moment is perceived to have been completed. Phil relates that he still feels the impact of aftershocks, much like getting used to the movement of a ship:

It's when you hear certain sounds, noises, frequencies, and feel vibrations. It's like being at sea and gaining your sea legs, then stepping ashore. You spend days getting rid of the urge to counterbalance the sway of the ship. That's the best way to illustrate what it's like to go through months of aftershocks; I've been through thousands of them, and I still feel them in my body. ${ }^{50}$

The earthquakes, quite simply, remain mobilized within bodies that have experienced them. Much like motion sickness that continues beyond the traveling moment, sensitivity to the earth's vibrations lives on after the earthquakes. The continuation of jolts, jiggles, and vibrations ${ }^{51}$ in the body that are recharged challenges a bounded sense of mobility. The journey does not quite end; we do not quite disembark but rather remain connected to the movement, the shock, the disrupted rhythm. ${ }^{52}$ In the following section, the movement of vibration sensitivity from one person to another is analyzed. Sara Ahmed's work on stickiness and the interchange of emotion is extended to note how subtle tremors are picked up and shared.

\section{Contagion-Vibration}


Mobilities draw on wide association with a number of emotions, such as exhilaration, excitement, happiness, anticipation, fearfulness, and anxiety, and as referred to above, some people become physically ill or sick to the stomach. ${ }^{53}$ I also draw here on Sara Ahmed's work to think about the movement of emotion between bodies, how bodies impact one another through fear. ${ }^{54} \mathrm{How}$ people feel about others is often what aligns us with a collective. Our bodily capacity to sense and react to fear is explained through Spinozian imagination, bodies affecting bodies. The bodily capacities of fear, as outlined by Ahmed, allow her to contemplate what the body does, whether fight or flight or paralysis, within a complex racial politics. I continue to take up Ahmed's ideas, through considering how objects can become sticky with affect. ${ }^{55}$ Examining the historical narrations (of earthquakes) that stick could allow for the immediacy of affect, the latency of vibration, and historical associations attached to the built environment during earthquakes to inform one another. So, this idea of stickiness reveals a history; it allows a focus on the context in which the traumatic event has occurred. Earthquakes are horrific, and the reoccurring trauma, the flashes of images that infiltrated participant accounts, could be informed by cultural histories and mass media images. When earthquakes are encountered (or even when they are not), there is already a portfolio of images of the risks and dangers embedded in our consciousness. The devastating scenes of building collapse, twisted concrete highways, outbreaks of fire, splintered cracks in the ground, bent rail lines, and so on construct a sense of the disaster. ${ }^{56}$ In this way, earthquakes are stuck in the subconscious (past) and flare up in the present. Trauma is also not confined solely to the bodies that experience it.

Trauma has also been considered "worryingly transmissible," ${ }^{57}$ but this is often in the relational context of shared experience—maybe not the exact same war, disaster, or experience of losing someone, but similarities exist in general terms. I argue that by being immersed in the 
research, vibration sensitivities were contagious, moving from survivors’ bodies to inhabiting my own. ${ }^{58}$ Since conducting the interviews, I have experienced a marked increase in awareness to vibrations that were imperceptible to me before conducting the research. Like participants, I now feel the elevator shaft as it moves up and down the building I work in, sending a cascade of minute shudders along each floor it passes. ${ }^{59}$ Shopping malls with underground carparks too are a source of stress, as they flex and vibrate with the weight of cars moving up and down the parking floors.

In one particular building, the heightened sensitivity to vibration came close to overwhelming my senses. I attended the Association of American Geographers' (AAG) conference in Los Angeles in 2013, housed in Fredric Jameson and Ed Soja’s “curiously incomprehensible” Westin Bonaventure. ${ }^{60}$ While attending sessions on the mezzanine floor, I became overwhelmed by the flex, shudder, and vibration of the building. No one but me panicked. I fled for the door, convinced of the oncoming earthquake. In talking later, I was met with puzzled responses; the tremors within the building were clearly not as obvious to others as

they were to me. This response links with historical associations. It had not been lost on me that I was visiting Mike Davis’s city, which “has been destroyed no less than 138 times in novels and films since 1909." ${ }^{61}$ A number of those times Los Angeles succumbed to earthquakes, both in popular fiction and reality, for example, the 1994 Northridge earthquake. As the projector screen shook and the floor quivered, movie images of shattered buildings formed in front of my eyes.

\section{Conscious Motion}

When disasters such as earthquakes struck, Christchurch’s city center propelled all sorts of mobilities that enabled and constrained bodies. For this article, a combination of the earth's 
movement, in seismic motion, embodied movement, and the movement of moorings, including buildings, have been collectively distilled. The tripartite analysis of mobility allows for discussion of a politics of microscale movement to be embedded in theories of emotion and affect. The affective flows of feeling that move between bodies in the disaster research setting have been examined; however, I have also thought about contagion of vibration sensitivity. The transmission of affect, how bodies belie their boundaries and impact one another, has immerged. ${ }^{62}$ By drawing on ideas of vicarious trauma and embodied experiences of posttraumatic stress disorder (PTSD), examination of the passing on of vibration sensitivity from survivor to researcher has been outlined.

It is now widely recognized that war veterans may suffer varying forms of PTSD, a cluster of psychiatric symptoms that manifest in varying forms upon the veterans' return "home." Veterans may have reactions to, or intensification of, symptoms by exposure to reminders of the stressor. ${ }^{63}$ Stressors can manifest in a multitude of different ways. In relation to this project, I am interested in connecting the environmentally stimulated stressors and embodied reactions to particular vibrations. Certain environments, such as busy urban settings (particularly for those returnees from Iraq) and/or particular technologies (such as helicopters), can cause intense embodied reactions, such as acute alertness and exaggerated startle reactions. ${ }^{64}$ In particular, Vietnam veterans can be sensitive to helicopter blades that pulse and reverberate through the air and send vibrations that (feel like they) hit the veteran's chest, causing intense bodily reactionsan example of the ordinary everyday meeting the extraordinary, causing an embodied reaction that fuses the present with the past. ${ }^{65}$ It has also been recognized that disaster survivors too can suffer from PTSD, and trauma is sticky with affect, in that it frequently fails to exit the body. Working with Ahmed’s historical associations to seismic events and their stickiness, I 
have also discussed how mass media images become embedded in the conscious mind, building an assortment of images and associations that reignite the senses. ${ }^{66}$ Flashes of buckled concrete and crushed buildings infiltrate into the present when similar vibrations are felt in the body: "the traumatized mind holds on to that moment" of impact. ${ }^{67}$ Sensitivity to vibration, then, is mobile and able to be shared and/or passed on to other bodies, linking together Teresa Brennan's transmission of affect ${ }^{68}$ at the microscale of the body. Cojoining these ideas of "vibration contagion” with work done on sense of motion, whether drifting along, in a state of travel disorientation, being aeromobile, or shaking/quivering on trains, has worked at the politics of relocation. ${ }^{69}$ In leaving Christchurch, the tremors continue to colonize the bodies of survivors, perhaps taking years to slowly seep out of consciousness. More work is needed on the intensely rich and embodied experiences of micromobilities; whether they be in the present or the past, they are instructive and push at the boundaries of what it means to be mobilized. Vibrational ontologies have allowed focus on buildings as able to live on, through and across bodies as vibrant matter, which extends mobilities work. Quite simply, life and materiality are brought closer together by examining material affects, and architecture is in the world in ways that are vital and active.

Gail Adams-Hutcheson is a teaching fellow in geography at the University of Waikato in Aotearoa New Zealand. Her research focuses on the emotional and affective spaces of transient communities in New Zealand. These communities include both postdisaster relocation and rural sharemilkers on the move. Her most recent article, "Spatialising Skin: Pushing the Boundaries of Trauma Geographies,” in Emotion, Space and Society, ties together psychoanalytical geographies with trauma studies. E-mail: gail.hutcheson@waikato.ac.nz 


\section{Notes}

I would like to acknowledge and thank Kimberley Peters for her support and comments on earlier drafts, as well as the detailed and helpful critiques offered by the anonymous referees whose time and effort are crucial to the finished article.

${ }^{1}$ Peter Adey, “If Mobility Is Everything Then It Is Nothing: Towards a Relational Politics of (Im)mobilities,” Mobilities 1, no. 1 (2006): 75-94, here 78.

${ }^{2}$ Mimi Sheller and John Urry, “The New Mobilities Paradigm,” Environment and Planning A 38, no. 2 (2006): 207-226, here 216.

${ }^{3}$ Jane Bennett, Vibrant Matter: A Political Ecology of Things (London: Duke University Press, 2010).

${ }^{4}$ On the fluidity of buildings, see Adey, "If Mobility Is Everything," 78; on elemental mobilities, see Peter Merriman, “Mobilities II: Cruising,” Progress in Human Geography 40, no. 4 (2015): 555-564, here 556.

${ }^{5}$ Elizabeth Grosz, Chaos, Territory, Art: Deleuze and the Framing of the Earth (New York: Columbia University Press, 2008), 32; see also 4-9.

${ }^{6}$ Grosz, Chaos, Territory, Art, 32.

${ }^{7}$ David Bissell, “Vibrating Materialities: Mobility-Body-Technology Relations,” Area 42, no. 4 (2010): 479-486, here 480.

${ }^{8}$ Bennett, Vibrant Matter, 20.

${ }^{9}$ Joanne Sharp, “Geography and Gender: What Belongs to Feminist Geography? Emotion, Power and Change,” Progress in Human Geography 33, no. 1 (2009): 74-80; see also Sara Ahmed, The Cultural Politics of Emotion (Edinburgh: Edinburgh University Press, 2004), 62-82; 
Deborah Thien, “After or Beyond Feeling? A Consideration of Affect and Emotion in Geography,” Area 37, no. 4 (2005): 450-456.

${ }^{10}$ Here I follow Melissa Wright in "not wanting to insert cleavage in otherwise friendly terms.” “Geography and Gender: Feminism and a Feeling of Justice,” Progress in Human Geography 34, no. 6 (2010): 818-827, here 821.

${ }^{11}$ Tim Cresswell, “Towards a Politics of Mobility,” Environment and Planning D: Society and Space 28, no. 1 (2010): 17-31, here 21-26.

${ }^{12}$ Geoff Wilson, “Community Resilience, Social Memory and the Post 2010 Christchurch (New Zealand) Earthquakes,” Area 45, no. 2 (2013): 207-215, here 210.

${ }^{13}$ Wilson, “Community Resilience,” 211.

${ }^{14}$ Cresswell, “Towards a Politics of Mobility,” esp. 26.

15 Tom Love, Population Movement after Natural Disasters: A Literature Review and Assessment of Christchurch Data (Melbourne: Sapere Research Group, 2011), http://www.srgexpert.com/wp-content/uploads/2015/08/Population-movement-after-naturaldisasters-a-literature-review-and-assessment-of-Christchurch-data.pdf.

${ }^{16}$ Mary Comerio, “Disaster Recovery and Renewal: Housing Approaches,” Cityscape: A Journal of Policy Development and Research 16, no. 2 (2014): 51-68.

${ }^{17}$ Cresswell, “Towards a Politics of Mobility,” 17-21.

${ }^{18}$ Kevin Hannam, Mimi Sheller, and John Urry, “Editorial: Mobilities, Immobilities and Moorings,” Mobilities 1, no. 1 (2006): 1-22, here 8.

${ }^{19}$ Gail Hutcheson, “Methodological Reflections on Transference and Countertransference in Geographical Research: Relocation Experiences from Post-disaster Christchurch, Aotearoa, New Zealand,” Area 45, no. 4 (2013): 477-484. See also Gail Adams-Hutcheson, "Voices from the 
Margins of Recovery: Relocated Cantabrians in Waikato,” Kotuitui New Zealand Journal of Social Science Online 10 (2015): 135-143; Gail Adams-Hutcheson, “Spatialising Skin: Pushing the Boundaries of Trauma Geographies,” Emotion, Space and Society, published electronically 26 March 2016, doi:10.1016/j.emospa.2016.03.002.

${ }^{20}$ Cresswell, “Towards a Politics of Mobility,” esp. 26; emphasis in original.

${ }^{21}$ Sheller and Urry, “The New Mobilities Paradigm,” 216. For an updated version of the past decade, see Mei-Po Kwan and Tim Schwanen, “Geographies of Mobility,” Annals of the American Association of Geographers 106, no. 2 (2016): 243-256.

${ }^{22}$ Henri Lefebvre, Rhythmanalysis: Space, Time and Everyday Life, trans. Stuart Elden and Gerald Moore (London: Continuum, 2004); Tim Edensor, ed., Geographies of Rhythm: Nature, Place, Mobilities and Bodies (Farnham: Ashgate, 2010), 1-8, esp. 1.

${ }^{23}$ Sarah Pink, "Sensing Cittáslow: Slow Living and the Constitution of the Sensory City,” Senses and Society 2, no. 1 (2007): 59-78, here 62; Holly Thorpe, “Natural Disaster Arrhythmia and Action Sports: The Case of the Christchurch Earthquake,” International Review for the Sociology of Sport 50, no. 3 (2015): 301-325.

${ }^{24}$ Simon Swaffield, “Place, Culture and Landscape after the Christchurch Earthquake,” in Space Place and Culture, ed. Helen Sykes (Albert Park, VIC: Future Leaders, 2013), 1-26.

${ }^{25}$ For work on cities, see Ash Amin and Nigel Thrift, Cities: Re-imagining the Urban (Cambridge: Polity, 2002). For mobilities work on disasters, see Mimi Sheller, “Air Mobilities on the US-Caribbean Border: Open Skies and Closed Gates,” Communication Review 13, no. 4 (2010): 269-288; Mimi Sheller, “The Islanding Effect: Post-disaster Mobility Systems and Humanitarian Logistics in Haiti,” Cultural Geographies 20, no. 2 (2013): 185-204.

${ }^{26}$ Edensor, Geographies of Rhythm, 8. 
27 Ibid., 5.

${ }^{28}$ Loretta Lees, “Towards a Critical Geography of Architecture: The Case of Ersatz Colosseum,” Ecumene: A Journal of Cultural Geographies 8, no. 1 (2001): 51-86, here 56; for work on affect and architecture, see also Peter Adey, “Airports, Mobility and the Calculative Architecture of Affective Control,” Geoforum 39 (2008): 483-451; Peter Kraftl, “Geographies of Architecture: The Multiple Lives of Buildings,” Geography Compass 4, no. 5 (2010): 402-415; Peter Kraftl and Peter Adey, “Architecture/Affect/Inhabitation: Geographies of Being-in Buildings,” Annals of the Association of American Geographers 98, no. 4 (2008): 213-231; Mark Llewellyn, “Polyvocalism and the Public: ‘Doing’ a Critical Historical Geography of Architecture,” Area 35, no. 3 (2003): 264-271.

${ }^{29}$ Nigel Clark, “The Time of Difference,” in “Geopower: A Panel on Elizabeth Grosz’s Chaos, Territory, Art: Deleuze and the Framing of the Earth,” special section, Environment and Planning D: Society and Space 30, no. 6 (2012): 971-988, here 976.

${ }^{30}$ Grosz, “Geopower,” in Geopower: a panel on Elizabeth Grosz’s Chaos, Territory, Art:

Deleuze and the Framing of the Earth. Environment and Planning D: Society and Space 30, no.6 (2012): 971-988, here 975.

${ }^{31}$ Nigel Thrift, “Intensities of Feeling: Towards a Spatial Politics of Affect,” Geografiska Annaler: Series B, Human Geography 86, no. 1 (2004): 57-78, here 56. Linking to the discussion of cities having a vibe or "atmosphere,” see James Ash, “Rethinking Affective Atmospheres: Technology, Perturbation and Space Times of the Non-human,” Geoforum 49 (2013): 20-28; Ben Anderson, “Affective Atmospheres,” Emotion, Space and Society 2 (2009): 77-81.

32 See also Sheller, “The Islanding Effect.” 
${ }^{33}$ Adey, “If Mobility Is Everything,” 78.

${ }^{34}$ Stephen Cairns and Jane Jacobs, Buildings Must Die: A Perverse View of Architecture

(Cambridge, MA: MIT Press, 2014).

${ }^{35}$ Adey, “If Mobility Is Everything,” 78.

${ }^{36}$ Philip England and James Jackson, “Uncharted Seismic Risk,” Nature Geoscience 4 (2011): $348-349$.

${ }^{37}$ New Zealand Police, “List of Deceased” as of 9 February 2012, http://www.police.govt.nz/major-events/previous-major-events/christchurch-earthquake/listdeceased (accessed 20 April 2016).

${ }^{38}$ Angela, interview transcript, 20 February 2012. Pseudonyms are used throughout.

${ }^{39}$ Interview transcript, 19 October 2012.

${ }^{40}$ Focus group transcript, 27 November 2011.

${ }^{41}$ Bissell, “Vibrating Materialities,” 480-481.

42 Ibid., 481; emphasis added.

43 Ibid., 479; emphasis in original.

${ }^{44}$ Lees, “Towards a Critical Geography of Architecture,” 56. See also the special issue on geographies of trauma in Emotion, Space and Society, in particular, Kate Coddington, “Contagious Trauma: Reframing the Spatial Mobility of Trauma within Advocacy Work, published electronically 23 February 2016, doi:10.1016/j.emospa.2016.02.002, and AdamsHutcheson, “Spatialising Skin.”

${ }^{45}$ Interview transcript, 11 November 2011.

${ }^{46}$ Interview transcript, 4 October 2011. 
${ }^{47}$ Interview transcript, 7 November 2011.

${ }^{48}$ For articles on the consequences of mobility, see David Bissell, "Passenger Mobilities: Affective Atmospheres and the Sociality of Public Transport," Environment and Planning D: Society and Space 28, no. 2 (2010): 270-289; Bissell, “Vibrating Materialities,” 480-481; Lucy Budd, “On Being Aeromobile: Airline Passengers and the Affective Experiences of Flight,” Journal of Transport Geography 19, no. 5 (2011): 1010-1016; Jon Anderson, “Exploring the Consequences of Mobility: Reclaiming Jet Lag as the State of Travel Disorientation,” Mobilities 10, no. 1 (2015): 1-16, here 2.

${ }^{49}$ As noted by Bissell, “Vibrating Materialities,” 485.

${ }^{50}$ Interview transcript, 25 October 2011.

${ }^{51}$ Bissell, “Vibrating Materialities,” 485.

52 Anderson, "Exploring the Consequences of Mobility."

${ }^{53}$ Peter Adey, Mobility (London: Routledge, 2010), 162-173. In particular, Mimi Sheller explains how movement links to emotion and causes embodied reactions such as feeling sick to the stomach; see Mimi Sheller, “Automotive Emotions: Feeling the Car,” Theory, Culture and Society 21, nos. 4-5 (2004): 221-242.

${ }^{54}$ Ahmed, The Cultural Politics of Emotion, 62-82.

55 Sara Ahmed, Queer Phenomenology: Orientations, Objects, Others (Durham, NC: Duke University Press, 2006).

${ }^{56}$ Mike Davis, Ecology of Fear: Los Angeles and the Imagination of Disaster (New York: Metropolitan Books, 1999), 1-9.

57 Roger Luckhurst, The Trauma Question (London: Routledge, 2008), 3.

${ }^{58}$ Hutcheson, “Methodological Reflections,” 477-484. 
${ }^{59}$ Susan, interview transcript, 12 February 2013.

${ }^{60}$ Fredric Jameson, Postmodernism, or, the Cultural Logic of Late Capitalism (Durham, NC:

Duke University Press, 1991), 39-45. See also Ed Soja, “Taking Los Angeles Apart: Some

Fragments of a Critical Human Geography,” Environment and Planning D: Society and Space 4, no. 3 (1986): 255-272.

${ }^{61}$ Davis, Ecology of Fear, 8.

62 Teresa Brennan, The Transmission of Affect (Ithaca, NY: Cornell University Press, 2004), 5174.

63 Sandra Janashak Verbosky and Deborah Ryan, "Female Partners of Vietnam Veterans: Stress by Proximity,” Issues in Mental Health Nursing 9, no. 1 (1988): 95-104.

64 Ibid., 97.

${ }^{65}$ Barbara Olasov Rauthbaum, Larry Hodges, Renato Alarcon, David Ready, Fran Shahar, Ken Graap, Jarrel Pair, et al., "Virtual Reality Exposure Therapy for PTSD Vietnam Veterans: A Case Study,” Journal of Traumatic Stress 12, no. 2 (1999): 263-271.

${ }^{66}$ Ahmed, The Cultural Politics of Emotion; Ahmed, Queer Phenomenology.

${ }^{67}$ Kai Erikson, A New Species of Trouble: The Human Experience of Modern Disasters (New York: W. W. Norton, 1994), 185.

68 Brennan, The Transmission of Affect, 51-74.

${ }^{69}$ On drifting, see Karen Peters, “Drifting: Towards Mobilities at Sea,” Transactions of the Institute of British Geographers 40, no. 2 (2015): 262-272; on shaking or quivering, see Bissell, “Vibrating Materialities,” 480-481; on being aeromobile, see Budd, “On Being Aeromobile,” 1010-1016; on states of travel disorientation, see Anderson, "Exploring the Consequences of Mobility,” 2. 